\title{
Efficient Irrigation for Florida-Friendly Edible Landscapes $^{1}$
}

\author{
Jacqlyn Rivas, Tiare Silvasy, Luke Harlow, Lynn Barber, Jennifer W. Marvin, Esen Momol, Tina \\ McIntyre, and Terra Freeman²
}

\section{Introduction}

A Florida-Friendly edible landscape utilizes nine core principles to conserve water and soil resources. This article focuses on Florida-Friendly Landscaping ${ }^{\mathrm{mat}}$ (FFL) principle \#2, watering efficiently, which promotes water conservation and plant health in the edible landscape. A consistent and efficient supply of water is essential for edible crops, including fruits, vegetables, and herbs. Edibles require regular watering for optimal production. Following guidance by FFL principles can help us water in the most efficient way possible, allowing Floridians to have good, edible landscape food production and conserve water resources. This EDIS publication is written for Florida gardeners, homesteaders and other horticulturalists interested in planting and establishing edible landscapes and improving those landscapes by conserving water. This publication will provide guidance for choosing the ideal irrigation system for edible cropping systems as well as general tips for conserving water in edible landscapes.

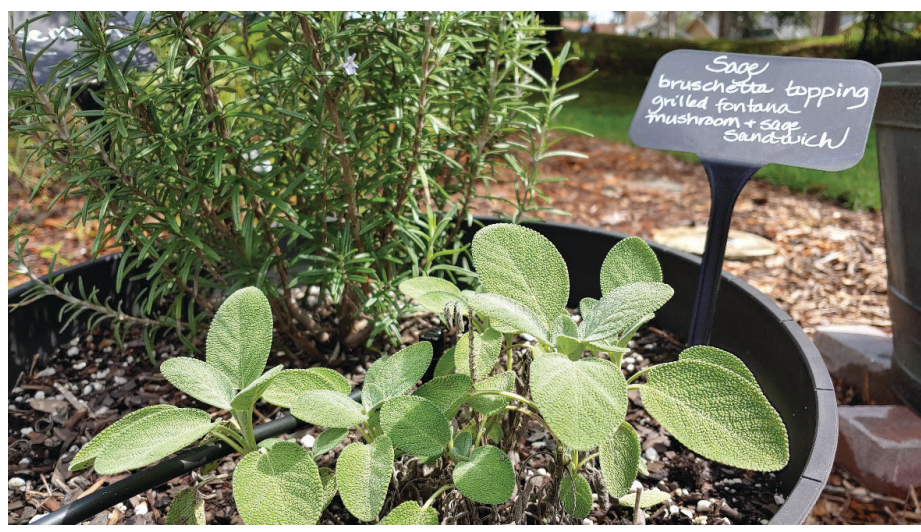

Figure 1. Drippers are an efficient way to water edibles, such as these herbs, in containers.

Credits: Jacqlyn Rivas, UF/IFAS

\section{Irrigation Management in the Edible Landscape}

Edible plants have specific watering requirements and will benefit from proper irrigation management. Watering efficiently requires knowing soil type and the plants' watering needs and planning irrigation schedules based on those needs. Without planning, this can be difficult in the edible landscape because established ornamentals require

1. This document is ENH1353, one of a series of the Environmental Horticulture Department, UF/IFAS Extension. Original publication date February 2022. Visit the EDIS website at https://edis.ifas.ufl.edu for the currently supported version of this publication.

2. Jacqlyn Rivas, microirrigation program coordinator, UF/IFAS Extension Hillsborough County; Tiare Silvasy, Extension agent II, residential horticulture and Florida-Friendly Landscaping ${ }^{\text {TM }}$, UF/IFAS Extension Orange County; Luke Harlow, Extension agent I, agriculture/natural resources/invasive species/4-H \& youth, UF/IFAS Extension Union County; Lynn Barber, Program county Extension agent II, Florida Friendly Landscaping ${ }^{\mathrm{TM}}$, UF/IFAS Extension Hillsborough County; Jennifer W. Marvin, Extension program manager, Florida-Friendly Landscaping ${ }^{\mathrm{TM}}$ Program, UF/IFAS Center for Land Use Efficiency; Esen Momol, director, Florida-Friendly Landscaping ${ }^{\text {TM }}$ Program; Tina McIntyre, Extension agent I, Florida-Friendly Landscaping ${ }^{\mathrm{TM}}$, UF/ IFAS Extension Seminole County; and Terra Freeman, Extension agent III, urban/commercial horticulture, UF/IFAS Extension St. Johns County; UF/IFAS Extension, Gainesville, FL 32611.

The Institute of Food and Agricultural Sciences (IFAS) is an Equal Opportunity Institution authorized to provide research, educational information and other services

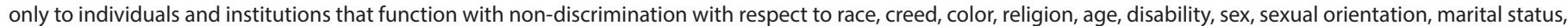

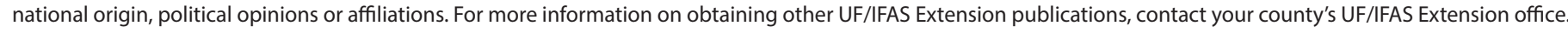
U.S. Department of Agriculture, UF/IFAS Extension Service, University of Florida, IFAS, Florida A \& M University Cooperative Extension Program, and Boards of County Commissioners Cooperating. Andra Johnson, dean for UF/IFAS Extension. 
less water compared to vegetables. Irrigation requires attention in this unique landscape due to varying plant water requirements.

\section{How much water do my edible plants need?}

Edible plants need just the right amount of water. Excessive or insufficient water can cause stress to the plant, fruit drop, and reduced vegetative and root growth, as well as promote disease and pest susceptibility. Plants require water for photosynthesis and transportation of essential nutrients. Vegetables require about one to two inches of water per week depending on the plant, season, and soil type. Irrigate when the first one to two inches of soil surface are dry. Use your fingers to physically check the soil or use a soil moisture sensor. Edibles have critical watering periods that support growth stages, like germination, flowering, and fruiting. Use a proactive approach by regularly monitoring plant appearance and adjusting watering frequency or duration as needed. This can reduce problems in the vegetable garden and increase harvest.

Seedlings and younger plants will require more frequent watering, especially when evaporative rates are high. As plants mature, watering duration should increase, and frequency should decrease. In other words, larger plants should be watered longer but less often. Both underwatering and overwatering can disrupt root systems and effect nutrient absorption. Use Table 1 to determine general watering needs for edibles during their growth stages.

\section{Underwatering}

Without adequate water, plants can become stressed and stunted and produce poorly. Plant wilting is a primary symptom of underwatering and indicates plant distress. Prolonged underwatering will result in nutrient deficiency, indicated by leaf discoloration, and may result in plant death. For example, fluctuating soil moisture may leach calcium from the soil or limit calcium absorption, causing blossom end rot in tomatoes. Fruiting plants may drop their flowers and fruits during times of water/drought stress. Plant wilting can also occur from excessive heat on hot sunny days, even when plants are hydrated. Check your plants in the morning or evening to see if they reflect appropriate moisture.

\section{Overwatering}

Overwatering may exhibit the same symptoms as underwatering, but the soil will be wet or saturated. Overwatering is likely to cause diseases and increase pests, such as insects and weeds. With too much water, the soil can be depleted of oxygen and lead to root rot and other problems. Excessive water may be caused by poorly drained soil and compaction. Certain fruits/vegetables like tomatoes and carrots may split due to excess or uneven watering. Some varieties are more prone to splitting. Too much water can lead to localized nutrient loss and pollute local water bodies through leaching or runoff. This is only an issue with nitrogen and phosphorus, two nutrients that negatively affect waterbodies.

\section{Types of Irrigation}

There are many types of irrigation, and more than one method might be required in the edible landscape because the plants have different water requirements. Rainfall should be the primary form of watering the garden. Using a rain gauge can help track rainfall. Use of harvested rainwater, such as rain barrel water, should only be for nonedible ornamental plants due to physical, biological, and chemical contamination. For additional information on the topic, please refer to Edible Landscaping Using the Nine Florida-Friendly Landscaping ${ }^{\mathrm{mu}}$ Principles: https://edis.ifas. ufl.edu/publication/EP594.

When rainfall cannot satisfy plant water requirements, supplemental irrigation for edibles should be used. The three common types of irrigation are high flow/volume in-ground, hand watering, and microirrigation (Figure 2). Turfgrass, ornamentals and edibles require different amounts of water and should be in separate zones. Establishing ornamentals and edibles requires frequent watering, and local ordinances may limit watering days and use. Check with your local Water Management District and local municipalities for watering use restrictions: https://floridadep.gov/water-policy/water-policy/content/ water-management-districts.

\section{In-Ground Irrigation}

In-ground irrigation (traditional/high volume/overhead) is used to irrigate turfgrass and is generally not recommended for ornamentals or edibles. Water streams from pop-up sprayers and rotors can damage delicate plants. Additionally, plant interference can cause uneven water distribution in turfgrass and landscape beds. Rotary nozzles are low volume and can be used for edibles integrated into large landscape areas and in orchards where there are groundcovers. If turfgrass is part of your edible landscape, convert to water-efficient nozzles. 


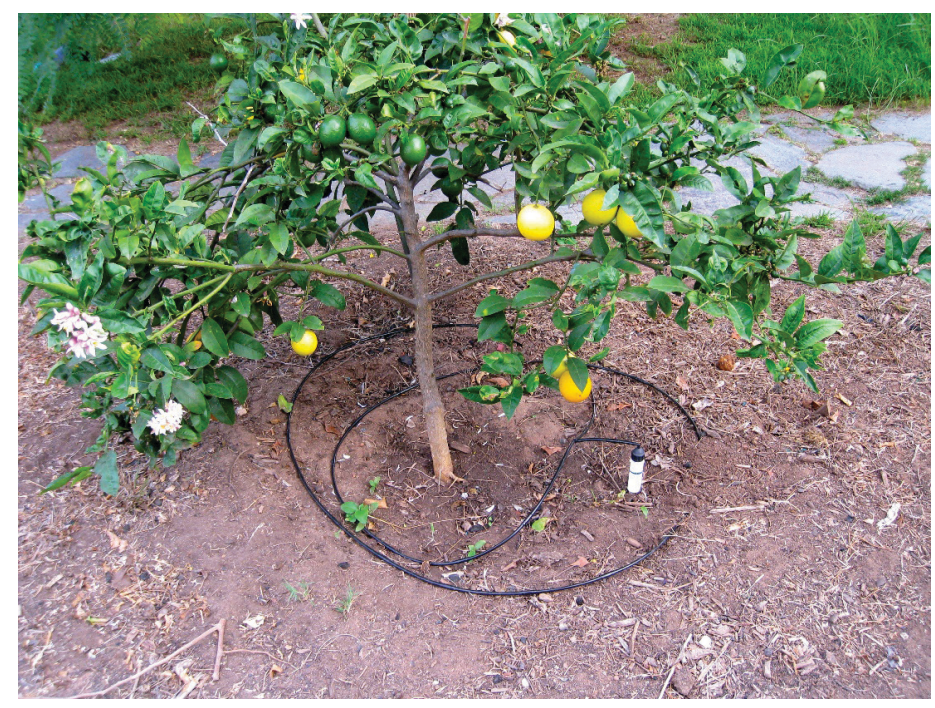

Figure 2. This dripline has two loops around this fruit tree to provide even watering around the root zone.

Credits: Luke Harlow, UF/IFAS

\section{Hand Watering}

Hand watering can be a very efficient way to water edibles. It involves a user holding a watering device like a hose or watering can. A hose nozzle with multiple watering patterns such as shower or garden settings work well. Check the soil to ensure that the water has permeated several inches into the soil after watering. Although useful for young plants, light surface watering will encourage shallow roots and make plants less drought tolerant. Deep watering in the root zone is relative to the plant you are growing (6" for seedlings and smaller crops, 24 " for shrubs and fruit trees) is better and encourages deep roots. Use a timer to avoid overirrigating.

Hand watering is good for transplants, for establishing new crops, and in smaller gardens, and it can also be a great method for maintaining more mature crops. It can be restrictive in larger gardens and during times of drought. Consider combining this watering method with microirrigation for larger gardens. If the soil gets too dry, hand watering may be needed to apply a larger volume of water to rewet the soil.

\section{Microirrigation}

Microirrigation is a low-volume, low-flow system that delivers water to the root zone. It can be a very efficient method of watering when used appropriately. Benefits include:

- Reduced weed populations

- Prevention of plant disease by wetting the soil instead of wetting the foliage (Figure 3)
- Reduced evaporation and direct application of water to the soil. Microirrigation systems usually function at 15 to 30 psi (pounds per square inch). To avoid blowing out lines or emitters, use a pressure regulator. To learn more about microirrigation, see Microirrigation for Home Landscapes: https://edis.ifas.ufl.edu/publication/AE524.

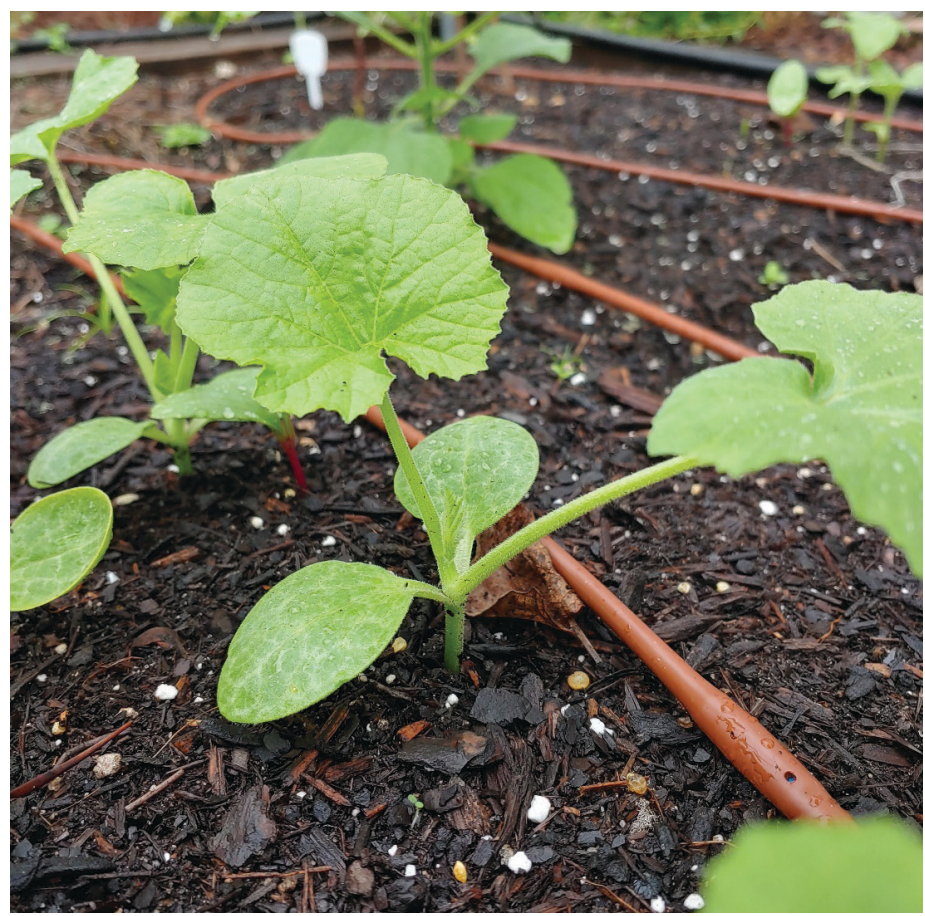

Figure 3. This dripline directly waters the soil and is ideal for squash, which are prone to fungal issues when leaves remain wet. Credits: Jacqlyn Rivas, UF/IFAS

\section{Watering Edibles with Microirrigation}

Consider using different types of microirrigation for different fruits and vegetables, herbs, and fruit trees. Types of microirrigation include dripline, drip emitters, microsprays, and microbubblers (Table 2).

\section{Dripline}

Drip emitters are preinstalled into in-line drip tubing. This system requires the least amount of setup. Drip tubing has a lower flow rate compared to drippers, bubblers and microsprays and is available in $1 / 4$-inch or $1 / 2$-inch diameters. Depending on manufacturer, emitters may be spaced every $6,9,12,18$, or 24 inches and have a flow rate of 0.5 to 1 gallon per hour. In-line drip tubing is ideal for row crops and raised garden beds. If customized spacing is required, consider using self-piercing drippers installed into $1 / 2$-inch supply tubing instead of in-line drip tubing.

\section{Drip Emitters}

Drip emitters or drippers are good options for potted vegetables and vegetables that do not like wet foliage, 
because water sitting on the leaves can cause plant disease problems. Drippers are attached to $1 / 4$-inch distribution tubing, secured with a stake, and set by the root zone. No spraying or misting occurs. Flow rates can range from 0.5 gallons per hour to 6 gallons per hour for low-flow drippers. Medium-flow emitters are ideal for watering larger shrubs and trees and can have a flow rate of 7-24 gallons per hour. Some drippers are self-piercing and can be directly installed into $1 / 2$-inch supply tubing for row crops, fruiting shrubs and trees.

\section{Microsprays}

Microsprays are available in different watering patterns and distribution rates up to 40 gallons per hour. Likewise, microsprays also vary in the diameter of area they water. Most range 2-4 feet, but some can go up to a diameter of 25 feet. Because microsprays irrigate a larger area, they can spray outside of raised garden beds and increase the growth of weeds. Sprayers can also cause drift by producing mist when water pressure is too high. Sprayers with downward streams are less likely to cause drift.

Microsprays can be good options for cool-weather crops such as carrots, radishes, and greens (Figure 4). They are not good options for vegetables like squash that are prone to fungal issues. Taller vegetables like mature collards can block microsprays. This plant interference causes uneven water distribution, resulting in over- and underwatered plants. When purchasing microsprays for vegetable gardens, look for sprayers that have an adjustable diameter and consider adjusting or using taller stakes/risers. Manufacturers have developed variations of microsprays and may include microjets, misters, spinners, or sprinklers. Some products include factory-installed stakes and on/off valves. Most products function between 10 and 30 psi. Overlapping coverage can reduce dry spots and watering duration.

\section{Bubblers}

Bubblers are versatile and can emit up to 26 gallons per hour depending on the type. Water emission can vary from multistreams (Figure 5) to umbrella-like streams in 180and 360-degree patterns. Microbubblers are good options for container gardens. Bubblers with higher flow rates are ideal for establishing larger fruit trees and shrubs. Most bubblers are adjustable and can be increased, decreased, or turned off. Bubblers work well for vegetables in raised beds, shrubs, trees, and plants such as blueberries.

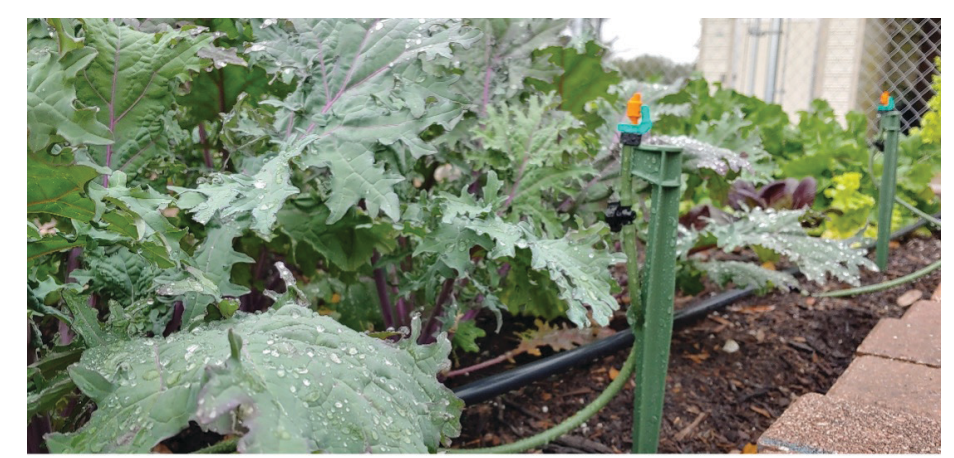

Figure 4. Microsprays are used to water kale in this small garden. Credits: Jacqlyn Rivas, UF/IFAS

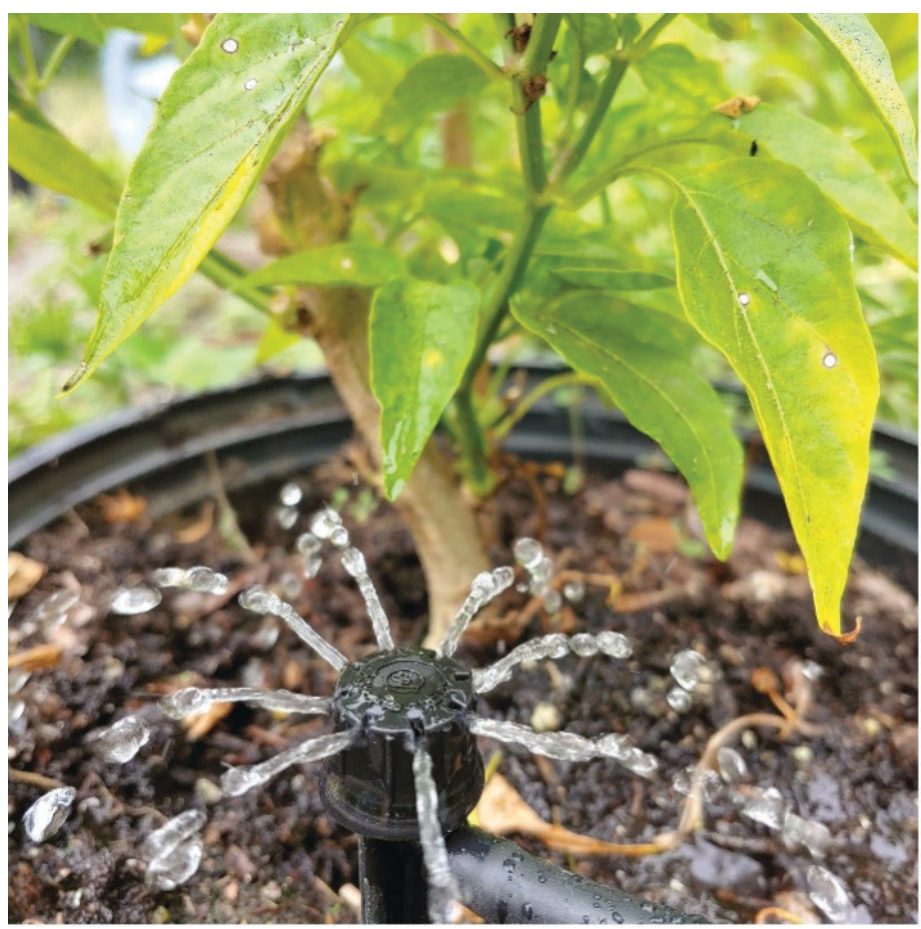

Figure 5. The microbubblers can be adjusted to apply more or less water to this pepper plant.

Credits: Jacqlyn Rivas, UF/IFAS

\section{Florida-Friendly Landscaping ${ }^{\mathrm{TM}}$ Water-Saving Strategies}

- Right Plant, Right Place. Select the right plant for the right place in your landscape based on your site conditions. Grow varieties known to produce well in Florida, like 'Everglades' tomato or 'Seminole' pumpkin. See the Florida Vegetable Gardening Guide (https://edis.ifas.ufl. edu/publication/VH021) for recommended vegetable varieties and Dooryard Fruit Varieties (https://edis.ifas.ufl. edu/publication/MG248).

- Choose drought-tolerant plants. Examples of plants that can withstand water stress include lemongrass, rosemary, loquat, mulberry, fig, and persimmon. See the FFL Plant Guide at https://ffl.ifas.ufl.edu/plants. 
- Design an efficient irrigation system. Choose the appropriate irrigation system for your edibles by checking product specifications, including pressure, run length, and flow rate. Mixing zones to include multiple forms of microirrigation is not recommended. See Basic Tips for Designing Efficient Irrigation Systems: https://edis.ifas.ufl. edu/publication/AE539.

- Adjust your irrigation system. Retrofit sprinkler systems to use microirrigation or water-efficient nozzles. Adjust irrigation controllers seasonally based on plant water requirements and local water restrictions.

- Conduct periodic maintenance. Frequently check for irrigation leaks, damage, and clogging. See Frequency of Residential Irrigation Maintenance Problems: https://edis. ifas.ufl.edu/publication/AE472.

- Retain soil moisture. Amend soil with compost to improve water retention. Use a 2"-3" layer of settled mulch for edible shrubs and trees, and a light layer of pine straw, pine needles or hay for vegetables. See Recycling Organic Materials to Improve Your Florida-Friendly Edible Landscape: https://edis.ifas.ufl.edu/publication/ep599.

- Water early. The best time to water is early in the morning between 4 a.m. and 6 a.m. Most ordinances require watering before $10 \mathrm{a} . \mathrm{m}$. or after 4 p.m. to minimize water loss to evaporation.

\section{Summary}

Edible landscaping has a specific goal, to provide a food source, and gardeners must use a proactive approach to increase success. Hand watering and microirrigation are both water-efficient approaches that can assist gardeners with plant maintenance as water demand, population and gardening interests increase. With proper planning and irrigation practices, gardeners can mitigate plant health issues, increase harvest, and maintain a healthy, edible landscape.

\section{References}

Bayabil, H. K., K. W. Migliaccio, M. Dukes, and L. Vasquez. 2020. "Basic Tips for Designing Efficient Irrigation Systems.” EDIS 2020 (1). https://doi.org/10.32473/ edis-ae539-2020

Boyer, M., and M. Dukes. 2020. "Estimated Water Saving Potential of Florida-Friendly Landscaping ${ }^{\mathrm{ma}}$ Activities." EDIS 2015 (3). https://edis.ifas.ufl.edu/publication/AE515
Brown, S., D. Treadwell, J. Stephens, and S. Webb. 2021.

"Florida Vegetable Gardening Guide." EDIS 2009 (2).

https://edis.ifas.ufl.edu/publication/VH021

Florida Department of Environmental Protection. 2019. "Water Management Districts." https:// floridadep.gov/water-policy/water-policy/content/ water-management-districts

Freeman, T., T. McIntyre, T. Silvasy, L. Barber, T. Wichman, E. Momol, J. Rivas, and J. Marvin. 2021. "Recycling Organic Materials to Improve Your Florida-Friendly Edible Landscape." EDIS 2021 (1). https://doi.org/10.32473/ edis-ep599-2021

Kemble, J. K., and D. C. Sanders. 2000. Basics of Vegetable Crop Irrigation. ANR1169. Alabama Cooperative Extension System. https://www.irrometer.com/pdf/research/anr-1169. pdf

Lott, D., and V. E. Hammond. 2013. Water Wise: Vegetable and Fruit Production. G2189. Institute of Agriculture and Natural Resources University of Nebraska at Lincoln. https://extensionpublications.unl.edu/assets/pdf/g2189.pdf

Olmstead, T. R., and M. D. Dukes. 2020. "Frequency of Residential Irrigation Maintenance Problems.” EDIS 2011 (2). https://edis.ifas.ufl.edu/publication/AE472

Silvasy, T., L. Barber, E. Momol, T. McIntyre, T. Wichman, G. Hansen, J. Marvin, T. Freeman, J. Sewards, W. Wilber, and J. Rivas. 2020. "Edible Landscaping Using the Nine Florida-Friendly Landscaping ${ }^{\mathrm{Tm}}$ Principles.” EDIS 2020 (5). https://doi.org/10.32473/edis-ep594-2020

UF/IFAS Florida-Friendly Landscaping ${ }^{\mathrm{TM}}$ Program. 2021. "FFL Plant Guide." https://ffl.ifas.ufl.edu/plants

Williamson, J., J. Crane, R. Rouse, and M. Olmstead. 2018. "Dooryard Fruit Varieties." EDIS 1994 (2). https://edis.ifas. ufl.edu/publication/MG248

Yasalonis, A., and M. Dukes. 2017. "Microirrigation for Home Landscapes.” EDIS 2017 (5). https://doi. org/10.32473/edis-ae524-2017 
Table 1. Watering Needs for Edible Crops during Their Growth Stages.

\begin{tabular}{|l|l|l|l|}
\hline Plant Type & Examples & Relative Water Need & Notes \\
\hline Microgreens, Sprouts & Seeds, sprouts, young transplants & High & Needs frequent watering in small amounts \\
\hline Annuals (Fruits and Vegetables) & $\begin{array}{l}\text { Green beans, sweet peas, cucumber, } \\
\text { carrot, strawberries, tomato, lettuce }\end{array}$ & High & $\begin{array}{l}\text { Regular water needed throughout the } \\
\text { growing season }\end{array}$ \\
\hline Long-Lived Vegetables & $\begin{array}{l}\text { Kale, collards, pumpkin, sweet } \\
\text { potatoes }\end{array}$ & $\begin{array}{l}\text { Can handle water stress after } \\
\text { establishment }\end{array}$ \\
\hline Established Perennials & $\begin{array}{l}\text { Pineapples, grapevines, blueberries, } \\
\text { blackberries, hops }\end{array}$ & $\begin{array}{l}\text { Need steady water for optimal production, } \\
\text { especially during flowering and fruiting }\end{array}$ \\
\hline Mature Herbs & $\begin{array}{l}\text { Basil, rosemary, chives, oregano, } \\
\text { thyme, parsley, fennel }\end{array}$ & $\begin{array}{l}\text { Herbs have varying water needs and soil } \\
\text { moisture preferences/tolerances, research } \\
\text { herb varieties before planting }\end{array}$ \\
\hline Established Fruit Trees & $\begin{array}{l}\text { Avocado, apple, mango, papaya, } \\
\text { banana, peach }\end{array}$ & $\begin{array}{l}\text { Need steady water for optimal production, } \\
\text { especially during flowering and fruiting }\end{array}$ \\
\hline
\end{tabular}


Table 2. Microirrigation Types and Uses.

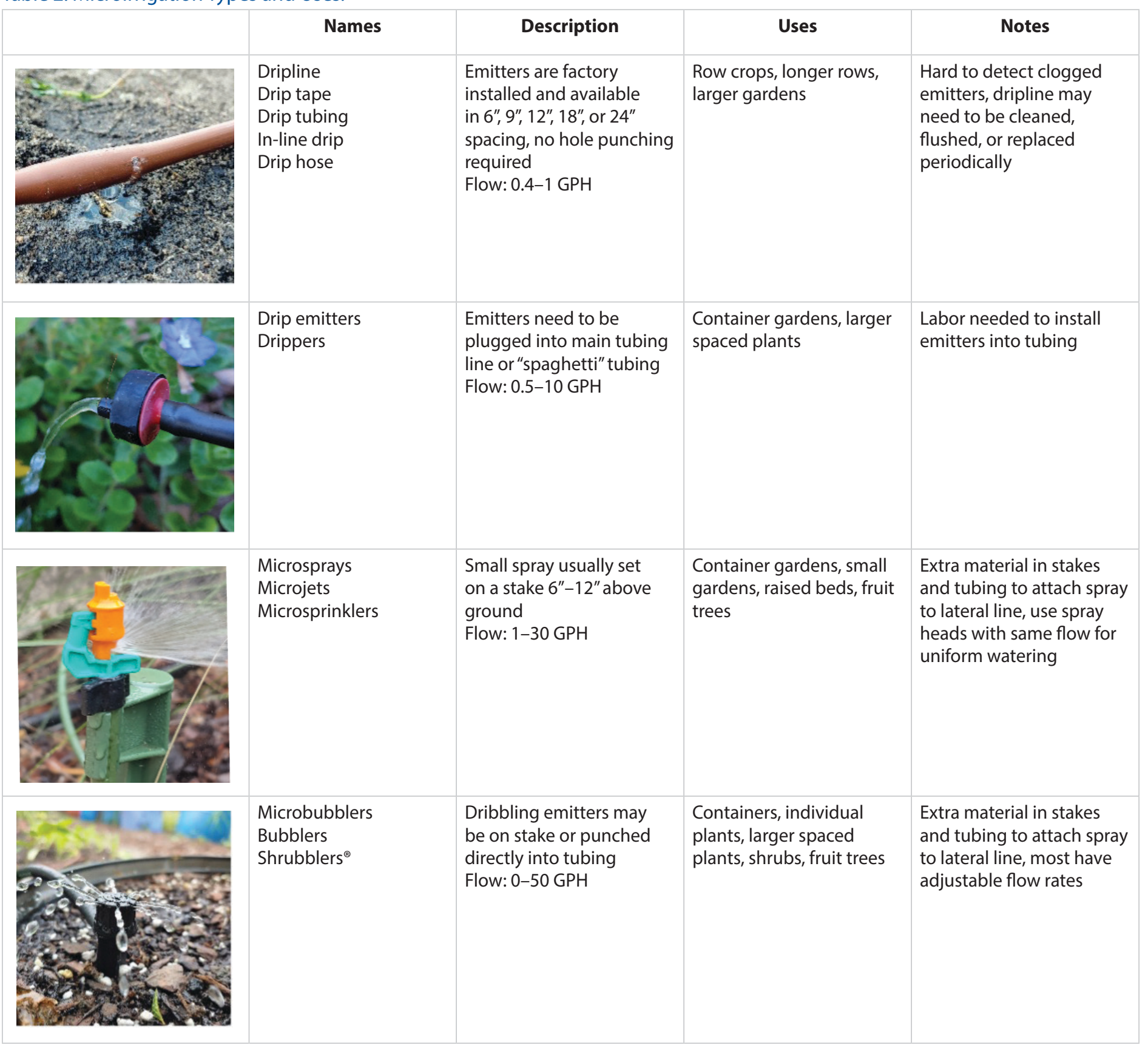

